DOI https://doi.org/10.30525/978-9934-26-004-9-27

\title{
ДЕМОНОЛОГІЧНІ СЮЖЕТИ У КНИЖКОВИХ МІНІАТЮРАХ: ОБРАЗ, ТЕКСТ, КОНТЕКСТ
}

\author{
Кметь В. C. \\ кандидат філологічних наук, бібліотекар I категорії \\ Наукової бібліотеки \\ Львівського національного університету імені Івана Франка \\ м. Львів, Украӥна
}

Процес візуалізації демонічного світу часто залежав від кількох факторів: юдео-християнської традиції, впливу народного та апокрифічного фактору, досвіду контакту людини із представниками інших етносів, книжної традиції, а також психологічного чинника. Конструйований невербальний образ генетично пов'язаний з архетипним мисленням і є тим знаком людського світовідчуття, який із плином часу набуває рис сталого символу-коду. У дослідженні здійснено аналіз візуалізації демонічної сфери у книжних мініатюрах та ілюстраціях на матеріалах рідкісних стародрукованих видань XVI-XIX ст. Наукової бібліотеки ЛНУ ім. Івана Франка, а також відстежено кореляцію образівсимволів із текстом, їхне суголосся 3 іконографією та світським малярством. Виявлені сюжетні мініатюри, що торкаються теми дослідження, можна умовно поділити за такими темами: гріхопадіння Адама і Сви, вплив чортів і демонів, Валаамова ослиця, мотив смирення та викорінення гріха.

Часто демонічні постаті зображено із зооморфними ознаками, ця тенденція тісно пов'язана з досвідом контактів із представниками інших етносів. Традиція демонізації чужого сягає корінням часів стародавньої Греції, але процес ототожнення іншого 3 інфернальною сферою розпочало християнство - ще в IX ст. образ ворога (іновірця, чужинця) у мистецтві мав «недолюдські» та «надлюдські» риси, викликав страх $\mathrm{i}$ зневагу [1, с. 73]. Із плином часу образ чужого акумулював культурні стереотипи та символи, які закоренилися в системі як церковного світоглядного канону, так і в народно-демонологічних віруваннях. У книжковій мініатюрі, зокрема зображеннях ініціалів, часто присутні зооморфні символи та сюжети. Наприклад, кентаври, людино-змії, сатири тощо (видання: Антонія Радивиловського «Вінець Христов» (Київ, 1688), «Новий Завіт» (Чернігів, 1717), Іоана Златоустого «Бесіди 
на 14 послань св. Апостола Павла» (Київ, 1623), «Антифонарій, згідно 3 чином римського бревіарію, за декретом св. Триденського собору встановлений і Папою Пієм 5 Понтифіком ухвалений» (Краків, 1645).

Гріхопадіння Адама і Єви. Загалом сюжет про гріхопадіння маркований негативною конотацією - жінка як вмістилище зла. До того ж, він рясно підкріплений фольклорним та етнографічним матеріалом. Наприклад, згідно з народним оповіданням, Бог створив Сву з ребра, тому перша жінка згрішила, адже походить не від душі, яку створив Бог, а 3 тіла, що від Сатанаїла [11, с. 228]. Фольклорні версії сюжету про Адама і Сву переважно наслідують біблійний взірець, проте вбачають причину гріхопадіння саме у характері першожінки. Наприклад, македонське народно-демонологічне оповідання, у якому спокусницею чоловіка постала донька диявола, яка через яблуко потрапила в середину тіла чоловіка. Відтак демон прорік, що діятиме ззовні, а донька його знищуватиме чоловіка зсередини [9, с. 95].

Книжкові мініатюри про перше гріхопадіння людей відображають біблійну версію цього сюжету і відтворюють момент спокуси у двох варіантах - зі змієм і без нього. Наприклад, у таких виданнях, як: Іоан Златоуст «Бесіди на 14 послань св. Апостола Павла» (Київ, 1623), «Біблія» (Венеція, 1777), «Біблія» (Краків, 1777), «Біблія 3 конкорданцією, анотаціями та поясненнями» (Ліон, 1546).

Образ змія, що спокусив Сву, поступово став атрибутом демонізованої жінки - відбулась контамінація демонічного змія та жінки. Це досить яскраво ілюструє іконографічна традиція, у народних переданнях зловмисниця також зберігає семантичний зв'язок із плазунами. Культове значення змії притаманне багатьом давнім культурам, зокрема для Південно-Східної Свропи та Малої Азії. Можливо, продовженням давньобалканського культу змії стали старовинні кіпрські та критські зображення жінок-жриць зі зміями в руках [10, с. 469]. Змія часто супроводжує постать демонічної жінки (або чарівниці) в іконографічних зображеннях та світському малярстві. Зокрема, варто згадати зображення чарівниць на іконах Страшного суду, груди яких жалить змій. Яскраві зразки мистецької інтерпретації цього символу-образу дали художники-прерафаеліти та символісти. Наприклад, картина Дж. Вотерхауса «Ламія» (вплив давньогрецького міфологічного сюжету). Вагомий вплив на образ жінки-демона також мав кабалістичний міф про Ліліт. Не менш цікава робота представника академічного напрямку П. Шиндлера «Сва» («Спокуса»), насамперед психологічною напругою сюжету картини. Митець зафіксував момент 
переляку першожінки: вона затамувала подих - позаду ж Сви звивається змія, символ їі гріхопадіння.

Під впливом сюжету про перше гріхопадіння символ змії став атрибутом мотиву про спокуси та гріх у дещо ширшому контексті. Так, зустрічаємо алюзії до мотиву спокуси в оздобі ініціалів видання «Духовні діалоги» (Київ, 1714). Зокрема у розділі про чин покаяння та сповіді ініціал містить зображення чоловіків біля дерева 3 плодами, навколо якого звивається змій. Важливо наголосити, що текст у цьому випадку корелюється 3 оздобою буквиці. Мистецьке виконання ініціалу візуалізовує мотив спокуси, а зміст тексту апелює до покаяння.

Валаамова ослиця. Мотив про Валаамову ослицю також пов'язаний iз демонізацією чужинців. У протистоянні моавитян із євреями постає проблема чистоти віри та тих, хто іiі сповідує. Згідно зі Синайським законодавством будь-які магічні практики категорично заборонені («Ворожки [за перекладом із давньоєврейської митрополита Іларіона (Огієнка) - «чарівниці»] не залишай у живих» [Вих. 22, 17-18]). Квінтесенцію цього критерію вірності та чистоти дотримання вчення Сущого Бога можна вбачати в епізоді взаємин народу Ізраїля 3 моавитянами під час подорожі до обітованої землі. Проте Валаам благословив богообраний народ і виголосив: «Бог вивів їх з Сгипту (...) нема чаклунства у Якові і нема ворожіння в Ізраїлі» [Чис. 23, 22-23]. Ініціали «Римського градуалу» і краківського видання «Біблії» 1777 р. саме відображають момент, коли Валаам б’є ослицю, що зупинилась перед янголом, здіймаючим меч,

Образ жінки постфертильного віку. Народні прислів'я часто ілюструють негативну конотацію образу жінки похилого віку: «Де чорт сам не зможе, там бабу пошле» [7, с. 26] та інші. Цікаво, що подібні негативні відгуки знаходимо і в інших слов'янських народів, зокрема у південних слов'ян. Відома низка македонських народно-демонологічних оповідань про стару бабу, яку чорт намовив посварити подружню пару: «Чорт і баба, чоловік і жінка», «Чорт, що перетворився на бабу, убив чоловіка і жінку», «Чорт і стара баба» та інші. Більшість цих оповідань зводиться до основної сюжетної лінії: чорт ніяк не може нашкодити подружжю і кличе на допомогу стару бабу, якій легко вдається впоратися 3 цим завданням. Цей сюжет репрезентований і в українській літературі, зокрема в доробку О. Стороженка («Се така баба, що чорт їй на махових вилах чоботи оддавав»).

Народний сюжет про бабу-зловмисницю та чорта мав вплив і на церковну книжну традицію. Так, один із аркушів краківського Псалтиря XVI ст. проілюстрований мініатюрою, на якій зображено чорта, що подає 
літній жінці чоботи, почеплені на рогача. Імовірно, жінка є чарівницею, оскільки біля іiі ніг зображено відповідні атрибути. Жінку та чорта роз'єднує річка з кладкою, маркуючи межу між двома постатями. Відтак можна припустити, що так означено страх чорта перед чаклункою 3 надзвичайно лихою вдачею.

Вплив чортів і демонів. Цікава символіка ініціалів краківського видання Римського градуалу 1740 р., що зображують мучеництво чоловіка, який потерпає від дій злого духа. Прикметно, що ініціал часто корелюється із текстом, а зокрема у випадку, коли його використано для ілюстрації «Символу віри». Тож зображення міста на другому плані набуває виразно символічного значення - алюзія Граду Господнього. Чоловік, над яким збиткується демон, знаходиться за межами міста, а отже в силі чорта, що через спокусу і гріх зміг доступитися до своєї жертви. Порятунок - за мурами віри, покаяння, Господньої обителі.

\section{Література:}

1. Амішай-Майселс 3. Демонізація «іншого» в образотворчому мистецтві // Демонізація іншого. Антисемітизм, расизм і ксенофобія / під ред. Роберта С. Вістріча; пер. 3 англ. Г. Є. Краснокутський. Одеса: АО БАХВА, 2006. С. 61-90.

2. Антифонарій, згідно з чином римського бревіарію, за декретом св. Триденського собору встановлений і Папою Пієм 5 Понтифіком ухвалений. Краків, 1645.

3. Біблія з конкорданцією, анотаціями та поясненнями. Ліон, 1546.

4. Біблія. Краків, 1777.

5. Біблія. Краків, 1777.

6. Біблія. Венеція, 1777.

7. Галицькі приповідки і загадки / зібр. Григорієм Ількевичем. Львів, 2003. C. 26.

8. Златоуст Іоан. Бесіди на 14 послань св. Апостола Павла. Київ: Києво-Печерська Лавра, 1623.

9. Македонски народни приказни / приредил Марко Цепенков, Кирил Пенушлиски. Скопје: Матица македонска, 2009. Кн. 2. 399 с.

10. Мифы народов мира. Энциклопедия: в 2 т. Москва, 1991. Т. 1. (A-K). C. 469.

11. «Народная Библия»: Восточнославянские этиологические легенды. Москва, 2004. С. 228.

12. Новий Завіт. Чернігів: Типографія Троїцького Іллінського монастиря, 1717. Арк. 112. 
13. Радивиловський Антоній. Вінець Христов. Київ: Типографія Києво-Печерської Лаври, 1688. Арк.133.

14. Римський градуал з Григоріанським календарем. Антверпен, 1599.

15. Римський градуал. Краків: Типографія Великої колегії Краківського університету, 1740.

16. Psalterium. [Краків], XVI ст. Арк. 46 (Ps. LII : Dixit incipiens in corde non est Deus).

DOI https://doi.org/10.30525/978-9934-26-004-9-28

\title{
СИНТЕЗ УКРАЇНСЬКОЇ ТА ІТАЛІЙСЬКИХ ТРАДИЦІЙ В АРХІТЕКТУРІ КИСВА ХVIII - ХІХ СТОЛІТТЯ (НА ПРИКЛАДІ ТВОРЧОСТІ Ф. РАСТРЕЛЛІ ТА РОДИНИ БЕРЕТТІ)
}

\author{
Кузьмінець Н. П. \\ кандидат історичних наук, доцент, \\ доцент кафедри історії та культури Украӥни \\ Стадник О. О. \\ кандидат історичних наук, \\ доцент кафедри історії та культури Украӥни \\ Вінницького державного педагогічного університету \\ імені Михайла Коиюбинського \\ м. Вінниця, Украӥна
}

У кінці ХУІІІ-ХІХ столітті українська архітектура розвивалася у руслі європейських традицій, згідно з їх тенденціями та стильовими напрямами. Вона постійно збагачувалася та удосконалювалася, поповнювалася новими композиційними елементами. Українські майстри запозичували головні принципи будівництва європейських споруд, використовували планування палацово-паркових ансамблів, запрошували до співпраці провідних зарубіжних митців. Особливе місце серед них належить відомим архітекторам італійського походження Франческо Бартоломео Растреллі та родині Беретті - батькові Вінченцо і сину Алессандро, за проєктами та під безпосереднім керівництвом яких було зведено багато споруд у Києві. Ці непересічні будівлі по праву відносять до світової культурної скарбниці. Можна стверджувати, що вони докорінно змінили архітектурне обличчя міста, перетворивши його на справжню європейську столицю. I до 